\title{
KEPEMIMPINAN PEREMPUAN DALAM ERA MODERN
}

\author{
Woman Leadership In The Modern Era
}

\author{
Husain Hamka \\ Universitas Hasanuddin \\ Alamat: Jl Perintis Kemerdekaan Km.10 Makassar \\ Email: husain.hamka@yahoo.com
}

Naskah diterima tanggal 5 Juni 2012. Naskah direvisi tanggal 25 Agustus 2012. Naskah disetujui tanggal 9 Oktober 2012

\begin{abstract}
Perempuan dalam era modern ini sudah menjalani fungsi yang signifikan di ruang publik. Mereka tidak lagi terkungkung dalam ruang domestik. Bahkan banyak diantaranya telah menjadi pemimpin di komunitas, oirganisasi tertentu bahkan menjadi pemimpin negara. Meski demikian tak jarang perempuan masih diposisikan sebagai makhluk kedua (the second sex). Kenyataan ini nampak masih muncul dalam konteks keagamaan. Misalnya dalam kepemimpinan Islam mereka diposisikan sebaiknya tidak menempati jabatan tertinggi. Perempuan tetap di anggap tidak memiliki karakter laki-laki seperti pemberani dan kuat yang di anggap sebagai potensi untuk menjadi pemimpin. Tulisan ini akan mencoba mengurai persoalan kepemimpinan perempuan dengan menggunakan analisis sosiologi agama dan hasilnya agama dalam hal ini Islam memberikan kesempatan yang luas bagi perempuan untuk berkiprah dalam berbagai hal.
\end{abstract}

Kata kunci: kepemimpinan Islam, perempuan, sosiologi agama, ruang publik dan domestik

\begin{abstract}
Woman in the modern era has been undergoing a significant role in public context in which they are not confined to the domestic sphere anymore. In fact, many of them have become leaders in communities, certain organizations even a president of a nation. Nevertheless, women are still often positioned as the second creature. This fact seems still to occur in religiousness context. For instance, in Islamic leadership, they are considered not to be placed in the top position or leader. Women are still considered that they do not have male's character such as braveness and strangeness as the required potencies to be a leader. This paper will try to analyze the issue of woman leadership by using religion sociology analysis. Based on the result of the research, it was found that Islam religion provides wide opportunity for women to take part in a variety of ways
\end{abstract}

Keywords: Islamic Leadership, Female, Sociology of religion, public and domestic space

\section{PENDAHULUAN}

$\mathrm{P}$ erkembangan pemikiran bagi kaum perempuan dari tahun ketahun mengalami perkembangan yang signifikan. Hal ini terlihat semakin banyaknya kaum perempuan yang ikut dalam kanca politik maupun organisasi yang dapat mewakili kaum perempuan di berbagai jenis kegiatan di masyarakat. Dalam kaitan ini telah banyak wanita yang berhasil meraih jabatan, mulai dari yang rendah sampai posisi puncak dalam suatu lembaga atau negara. Bahkan sejarah telah mencatat beberapa wanita yang jaya di panggung politik dan menduduki jabatan menteri, wakil presiden hingga presiden atau perdana menteri bahkan sudah banyak perempuan menjadi ketua pengadilan, baik tingkat kabupaten maupun pada tingkat propinsi bahkan pusat pun sudah mulai ada.

Kenyataan ini, telah memunculkan polemik di kalangan umat Islam, khususnya para ulama, 
dan organisasi islam lainnya yang berkaitan dengan pandangan Islam terhadap keberadaan wanita dalam jabatan-jabatan strategis di sektor publikitu. Polemik ini berawal dari pandangan tentang perbedaan struktur biologis antara laki-laki dan wanita yang berimplikasi pada peran yang diembannya dalam masyarakat. Dari struktur anatomi biologis, wanita dianggap memiliki beberapa kelemahan yang lebih banyak dibandingkan dengan kaum laki-laki normal.

Oleh karena itu, anatomi biologi laki-laki sangat memungkinkan menjalankan sejumlah peran utama dalam masyarakat (sektor publik) karena dianggap lebih potensial, lebih kuat dan lebih produktif. Organ reproduksi dinilai membatasi ruang gerak wanita, karena secara kodrati mereka akan hamil, melahirkan dan menyusui. Sedangkan laki-laki secara kodrati tidak memiliki fungsi reproduksi tersebut. Perbedaan itu melahirkan pemisahan fungsi dan peran serta tanggung jawab antara laki-laki dengan wanita. Dalam hal ini lakilaki dipandang cocok berperan di sektor publik sedangkan wanita dipandang cocok berperan di sektor kerumah tanggaan.

Namun demikian bahwa penjelasan tentang "wanita" itu sendiri dalam bahasa Arab mempunyai konotasi inferior (lemah lembut, pelupa, penghibur, akalnya kurang) berlawanan dengan "laki-laki" yang dalam bahasa Arab berkonotasi superior (cerdas, berpikir, dan kuat).

Tampaknya pandangan tersebut didukung oleh tekstual QS. Al-Nisa (4): 34 bahwa: 'Kaum lakilaki itu adalah pemimpin bagi kaum wanita...'

Adapun makna ayat tersebut di atas dapat dipahami secara zahir (tekstual), yang seakan-akan menunjukkan bahwa yang layak menjadi pemimpin hanyalah laki-laki. Sebaliknya wanita hanya layak dipimpin oleh laki-laki. Pemahaman seperti ini diklaim mencakup segala aspek kehidupan dan peran sosial masyarakat. Dengan pemahaman ini, maka wanita tidak bisa menjadi pemimpin apalagi pemimpin pada posisi puncak dalam sektor publik. Wanita hanya cocok berperan di sektor domestik sebagai ibu rumah tangga.

Pemahaman tersebut mendasarkan argumentasinya pada sabda Nabi saw:

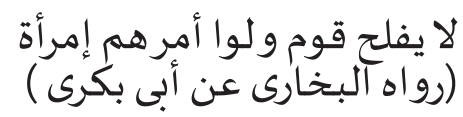

Artinya: 'Tidak akan beruntung (sukses) suatu kaum yang menyerahkan urusan mereka kepada perempuan.' (HR Bukhari dari Abu Bakrah)

Namun masalahnya adalah apakah memang demikian makna ayat 3 surat al-Nisa di atas? Jelasnya, apakah teks QS. Al-Nisa; 34 mengandung makna bahwa hanya laki-laki saja yang dianggap memiliki kualifikasi (keahlian) sebagai pemimpin, baik sebagai kepala rumah tangga (sektor publik), maupun dalam kehidupan sosial masyarakat (sektor publik)? Kalau memang demikian pemahamannya, maka apakah tidak akan melahirkan image bahwa al-Qur'an sebagai sumber ajaran Islam telah melakukan diskriminasi terhadap peran sosial antara laki-laki dengan perempuan? Pertanyaan ini perlu didiskusikan lebih lanjut.

Berdasarkan asumsi di atas, tulisan ini bermaksud menganalisis tentang perempuan yang menduduki jabatan kepala dalam perspektif sosiologis dan hukum Islam.

\section{PEMBAHASAN}

\section{Peran Perempuan Dalam Analisis Gender}

Ada dua perbedaan kehidupan sosial yang nyata bagi laki-laki dan perempuan, lingkungan masyarakat sebagai tempat pertama bagi laki-laki, dan perempuanlah yang akrab dengan lingkungan rumah tangga hubungan diantara keduanya adalah tidak langsung. Penafsiran yang diberikan kepada biologis perempuan menyebabkan kerugian mereka pada semua tingkat masyarakat bukan keadaan biologis mereka sendiri. Perempuan di manapun umumnya kurang dikenal dan kurang berwenang dalam adat. Penafsiran inilah yang mengikat mereka untuk hanya mengasuh anak-anak dan tetap dalam lingkungan rumah tangga.

Adapun yang menyebabkan perempuan kurang berpartisipasi dalam arena politik, yaitu :1) Secara kultural dan diperkuat oleh interpretasi agama perempuan berada di posisi subordinat terhadap laki-laki, masih dianggap sebagai mahluk yang berada di bawah kepemimpinan laki-laki, sehingga dalam pengambilan keputusan, berkaitan dengan kehidupan sosial, politik ekonomi maupun kehidupan pribadi itu sendiri umumnya perempuan tidak memiliki hak suara apalagi hak untuk mengambil dan menjalankan keputusan; 2) Akses perempuan terhadap ekonomi dan informasi sangat 
kecil. 3) Sejak dihancurkannya gerakan perempuan di masa orde baru, kemudian segera disusul dengan doktrin pencitraan perempuan yang dipaksakan. 4) Rasa percaya diri yang kurang Tjokrominoto, 1996: 31).

Dengan ketat melalui berbagai jalur legislatif, politik maupun budaya, perkembangan gerakan perempuan diarahkan menuju satu titik yaitu domestikasi perempuan, dengan meletakkan perempuan di dalam rumah tangga, sebagai isteri pendamping suami dan ibu dari anak-anaknya. Kebijakan ini menjadikan perempuan bersikap apolitis atau rendah kesadaran politiknya (H.Dian, 2002:25).

Dalam hal ini laki-laki di anggap mampu menjaga jarak dari lingkungan kehidupan rumah tangga sebagai akibatnya mereka tidak memerlukan komitmen pribadi terhadap orang lain sebagaimana yang diperlukan oleh ibu-ibu atau perempuan. Lakilaki lebih dihubungkan dengan wewenang abstrak dan dengan kehidupan politik dalam masyarakat sebagai suatu keseluruhan. Keterpisahan laki-laki dari lingkungan rumah tangga membuat mereka lebih cocok dalam keterlibatan ritual di ruang public.

Dengan demikian ini akan menyebabkan keterlibatan laki-laki dalam kehidupan politik dan keagamaan mendapat legitimasi melebihi perempuan yang difokuskan pada kehidupan rumah tangga. Perempuan memiliki kekuatan yang lebih sedikit dibanding laki-laki dalam masyarakat. Ketidakseimbangan antara jenis kelamin adalah lebih besar dalam masyarakat dibanding faktor lain, dan perempuan bisa menjadi lebih dekat persamaan jika laki-laki lebih terlibat dalam kehidupan rumah tangga.

Tjokroaminoto menekankan bahwa penyebab rendahnya partisipasi perempuan dalam pembangunan dan cenderung menempati posisi terbelakang adalah sebagai berikut : 1) Adanya dikotomi maskulin/feminin peranan manusia sebagai akibat dari determinasi biologis seringkali mengakibatkan proses marginalisasi perempuan; 2) Adanya dikotomi peran publik/ peran domestik yang berakar dari sindroma bahwa "peran perempuan adalah di rumah" pada gilirannya melestarikan pembagian antara fungsi produktif dan fungsi reproduktif antara laki-laki dan perempuan; 3) Adanya konsep "beban kerja ganda" yang melestarikan wawasan bahwa tugas perempuan terutama adalah di rumah sebagai ibu rumah tangga, cenderung mengalami proses aktualisasi potensi perempuan secara utuh; 4) Adanya sindroma subordinasi dan peran marginal perempuan telah melestarikan wawasan bahwa peran dan fungsi perempuan dalam masyarakat adalah bersifat sekunder (Tjokroaminoto, 1996: 59).

Selanjutnya Rasdiayanah) mengemukakan bahwa masih kuatnya pandangan-pandangan bahwa perempuan lebih cocok dengan pekerjaan-pekerjaan rumah tangga dibanding laki-laki, atau pandangan bahwa perempuan lebih menggunakan perasaannya dari pada rasional, sehingga perempuan tidak cocok dengan bidang-bidang pekerjaan yang keras dan rasional termasuk bidang politik yang dianggap hanya cocok dengan laki-laki. Ini merupakan gambaran mengenai adanya diskriminasi klasik terhadap perempuan (Andi Rasdiana, 1999: 41).

Potensi dasar yang dimiliki oleh perempuan sebagai makhluk religius, individu, sosial dan budaya sebenarnya tidak berbeda dengan laki-laki. Berbagai hasil penelitian tersebut menunjukkan tidak adanya perbedaan yang signifikan tentang kemampuan dasar potensial dari kedua jenis (laki-laki dan perempuan) tersebut. Bahkan pada beberapa penelitian, tanpak bahwa perempuan memiliki beberapa kelebihan khas, antara lain perempuan lebih mampu untuk berperan ganda, di samping mengembang kodratnya sebagai ibu yang mengandung, melahirkan, menyusui dan membesarkan anak dengan kasih sayang, perempuan memiliki potensi dasar untuk lebih tahan uji, rela berkorban, tahan menderita, ulet dan sabar dibanding laki-laki.

Hasil penelitian menunjukkan bahwa perempuan pada umumnya lebih tekun, ekonomis dan hemat sehingga mereka dapat dipercaya untuk menduduki posisi penting tertentu. Akan tetapi mengapa perempuan secara realitas terpinggirkan, termarginalisasi, tersubordinasi, terpuruk, tidak berdaya dan bahkan tereksploitasi diberbagai sektor kehidupan, khususnya dalam politik, dalam proses pengambilan keputusan dan penentuan kebijakan publik.

Bila dianalisis maka ternyata bahwa keadaan itu disebabkan oleh dua faktor yaitu: faktor internal perempuan, faktor ekternal. Antara lain yang 1) Faktor Internal yaitu perempuan bersumber dari 
kualitas perempuan itu sendiri. Sekalipun kuantitas perempuan besar jumlahnya, banyak perempuan yang berpotensi kurang memanfaatkan peluang dan kesempatan untuk meningkatkan kualitas diri melalui peningkatan wawasan pengetahuan, kemampuan pengendalian diri, berkomunikasi dan beraktualisasi sesuai dengan hati nurani kata hati yang suci dan luhur, sehingga perempuan berprestasi optimal dalam posisi apapun baik sebagai ibu, isteri, tokoh masyarakat dan professional; 2) Faktor Eksternal yaitu bersumber dari luar diri perempuan. Berbentuk antara lain dominasi laki-laki untuk tetap menjadi leader yang berimbas pada berbagai produk sosial budaya yang berpandangan merugikan dan tidak equal bagi perempuan. Lebih jauh lagi muncul penafsiran ajaran agama yang bertentangan dengan asas keadilan dan kesetaraan penciptaan manusia oleh sang Khaliq. Realitas tersebut telah memposisikan keterpurukan perempuan dalam kebodohan dan tidak keberdayaan serta kurang memberi peluang pada perempuan secara lebih berkeadilan.

\section{Peran Sebagai Pemimpin dalam Islam}

Sebenarnya antara laki-laki dan perempuan memiliki kesetaraan sebagai makhluk Tuhan. Setidaknya demikian yang dikatakan oleh Nasaruddin Umar. Menurutnya persamaan itu antara lain:

1) Laki-laki dan wanita sama-sama sebagai hamba Allah ('abid)

2) Laki-laki dan wanita sebagai khalifah di bumi

3) Laki-laki dan wanita menerima perjanjian primordial

4) Adam dan Hawa terlibat secara aktif dalam drama kosmis

5) Laki-laki dan wanita berpotensi meraih prestasi.

Maksudnya, bahwa dalam kapasitas manusia sebagai seorang hamba, laki-laki dan wanita berpotensi dan berpeluang yang sama untuk menjadi hamba ideal (orang bertakwa), sebagaimana diisyaratkan dalam QS. Al-Hujurat (49): 13. Di samping kapasitasnya sebagai hamba, manusia adalah khalifah di bumi. Dalam hal ini laki-laki dan perempuan mempunyai peran yang sama sebagai khalifah, yang akan mempertanggungjawabkan tugas-tugas kekhalifahannya di bumi, sebagaimana halnya laki-laki dan perempuan harus bertanggungjawab sebagai hamba Tuhan.

Begitu pula laki-laki dan perempuan samasama mengemban amanat dan menerima perjanjian primordial dengan Allah (QS. Al-A'raf (7): 172). Menurut Fakhru al-Razi, bahwa tak seorang pun anak manusia yang lahir di muka bumi ini yang tidak berikrar tentang ekstensi Tuhan. Ini berarti, bahwa dari aspek penerimaan perjanjian primordial itu, tidak ada perbedaan antara laki-laki dan perempuan (Fakhru, 1990: 57).

Semua ayat yang mengisahkan drama kosmis, yaitu cerita tentang keberadaan Adam dan Hawa di surga sampai keluar ke bumi, selalu menekankan kedua belah pihak secara aktif dengan menggunakan damir (kata ganti orang) untuk dua orang (huma) yang merujuk kepada Adam dan Hawa secara bersamaan. Penjelasan lebih rinci dikemukakan dalam QS. Al-Baqarah (2):35, al-A'raf (7): 20, 22, 23 serta al-Baqarah (2): 187.

Dalam meraih prestasi maksimal pun, lakilaki dan perempuan mempunyai potensi yang sama sesuai dengan QS. Al-Nisa (4): 124

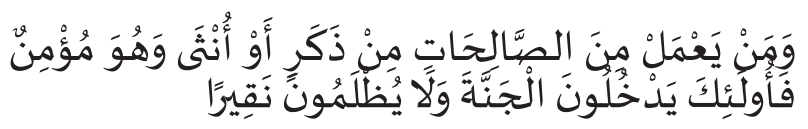

Terjemahnya:'Barangsiapa yang mengerjakan amal-amal shaleh, baik laki-laki maupun perempuan sedang ia orang yang beriman, maka mereka itu masuk ke dalam surga dan mereka tidak dianiaya walau sedikitpun'.

Dari ayat di atas dapat dikemukakan bahwa al-Qur'an telah mengakui kemitrasejajaran peran laki-laki dan perempuan. Bahkan secara substansial Rasulullah saw menegaskan:

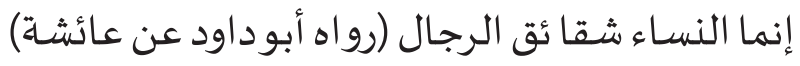

Artinya:'Sesungguhnya perempuan itu adalah belahan (mitra) laki-laki'. (HR Abu Daud dari Aisyah)

Karena itu pemahaman terhadap ayat dan hadis yang berkaitan dengan kepemimpinan laki-laki terhadap perempuan perlu diadakan reinterpretasi, termasuk fiqh. Dalam kaitan ini 
Amir Syarifuddin salah seorang pakar ushul fiqh di Indonesia mengatakan bahwa karena fiqh merupakan hasil pemikiran ulama mujtahid yang menurut dasarnya dapat mengalami perubahan dengan cara mengadakan reinterpretasi terhadap dalil yang menjadi sandaran bagi pemikiran tersebut (Amir Syarifuddin, 2002: 25).

Dengan demikian seandainya potensi perempuan selama ini dianggap kurang berkembang yang menyebabkan kekurang berdayaannya dalam kehidupan masyarakat banyak disebabkan oleh budaya masyarakat yang mengitarinya dan bukan disebabkan oleh ajaran agama yang berdasarkan wahyu dan petunjuk Nabi dalam sunnahnya. Dalil-dalil yang berkaitan dengan kepemimpinan perempuan dalam interaksi sosial bukanlah harga mati, mengingat tampilnya Siti Aisyah dalam kehidupan sosial dan politik dengan seizin Nabi dan begitu pula para sahabat Nabi belakangan tidak pula menghalanginya.

Bahkan al-Qur'an mengabadikan citra perempuan ideal yang mempunyai kemandirian politik, seperti sosok Ratu Balqis, penguasan perempuan yang mempunyai kekuasaan besar (super power), yang dikisahkan dalam QS. Al-Naml (27): 23:

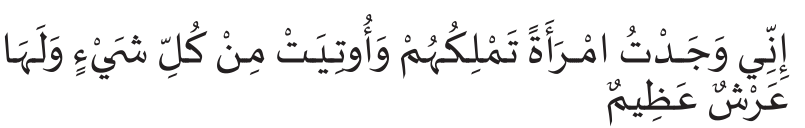

Terjemahnya:'Sesungguhnya aku menjumpai seorang perempuan yang memerintah mereka, dan dia dianugerahi segala sesuatu serta mempunyai singgasana yang besar.

Diabadikannya kisah Ratu Balqis (penguasan kerajaan Saba pada masa Nabi Sulaiman) ini mengisyaratkan bahwa al-Qur'an sumber pokok hukum Islam sejak dini telah mengakui keberadaan perempuan yang menduduki puncak kepemimpinan di sektor publik. Dengan kata lain, ayat ini secara tersirat membolehkan perempuan menjadi pemimpin, termasuk sebagai kepala negara sekalipun.

Karena itu pula ayat dan hadis yang secara zahirnya melarang perempuan menjadi pemimpin, perlu dikaji. Ayat tersebut di antaranya adalah QS. Al-Nisa: "Kaum laki-laki itu adalah pemimpin bagi kaum perempuan...."
Ayat ini harus dipahami secara komprehensif dan bukan sepotong-sepotong sebab dalam ayat ini ada kalimat lanjutannya, yakni "karena mereka (laki-laki) telah menafkahkan sebagian dari harta

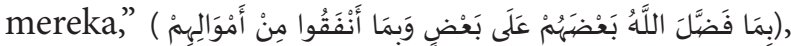
yang menunjukkan bahwa yang dimaksud adalah "kepemimpinan dalam keluarga (rumah tangga), dan itulah derajat yang diberikan kepada laki-laki." Sebagaimana ditegaskan dalam QS. Al-Baqarah (2): 228

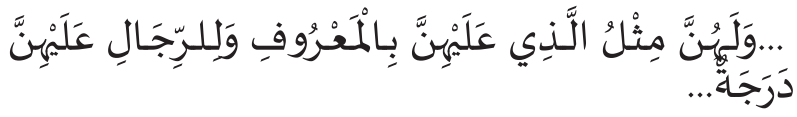

Terjemahnya: '... dan para perempuan mempunyai hak yang seimbang dengan kewajibannya menurut cara yang ma'ruf, akan tetapi para suami mempunyai satu tingkatan kelebihan daripada isterinya...

Ayat di atas menurut Rasyid Rida merupakan kaidah umum yang berbicara tentang kedudukan yang sama antara perempuan dan laki-laki dalam segala bidang, kecuali dalam masalah kepemimpinan dalam rumah tangga (Muhammad Rasyid, 1992: 47).

Penempatan laki-laki (suami) sebagai kepala rumah tangga itu sebenarnya merupakan respon terhadap kondisi sosial masrakat Arab menjelang dan ketika al-Quran diturunkan. Dalam hal ini peran laki-laki mendominasi berbagai bidang kehidupan termasuk dalam sistem keluarga. Dalam masyarakat Arab, laki-laki bertugas membela dan mempertahankan seluruh anggota keluarga, bertanggung jawab memenuhi seluruh kebutuhan anggota keluarga. Konsekuensinya, lakilaki memonopoli kepemimpinan dalam semua tingkatan.

Di samping itu ayat di atas secara tersirat menunjukkan bahwa secara kodrati, laki-laki "cenderung ingin melindungi perempuan (nature). Dengan kata lain, bahwa makna kata قَوًَامُونَ (nangat beragam, antara lain pelindung, pembimbing, pengayom, maupun pembimbing. Tampaknya, para mufasir dan fuqaha klasik lebih cenderung mengartikan قَوََامُونَ sebagai pemimpin ketimbang makna-makna lainnya. Bahkan menganggap "ayat ini menunjukkan bahwa lelaki berkewajiban mengatur dan mendidik perempuan, serta 
menugaskannya berada di rumah dan melarangnya keluar. Perempuan berkewajiban menaati dan melaksanakan perintah laki-laki selama itu bukan perintah maksiat.

Namun sekian banyak mufasir dan pemikir Islam kontemporer memandang bahwa ayat 34 surat al-Nisa tidak dipahami demikian, apalagi ayat tersebut berbicara dalam konteks kehidupan rumah tangga. Menurut Quraish Shihab, bahwa kata al-rijal dalam ayat al-rijal qawwamuna 'alan nisa, bukan berarti laki-laki secara umum, tetapi adalah "suami" karena konsiderans perintah tersebut seperti ditegaskan pada lanjutan ayat adalah karena mereka (para suami) menafkahkan sebagian harta untuk isteri-isteri mereka. Jika yang dimaksud dengan kata "laki-laki" adalah kaum laki-laki secara umum, tentu konsideransnya tidak demikian. Apalagi lanjutan ayat itu secara tegas berbicara tentang para isteri dan kehidupan rumah tangga (M. Quraish Shihab, 2005: 65).

Alasan kedua yang dijadikan dalil agama yang melarang perempuan menjadi pemimpin adalah hadis Nabi saw yang diriwayatkan oleh Abu Bakrah, bahwa "tidak akan beruntung suatu kaum yang menyerahkan urusan mereka kepada perempuan." Dalam hal ini hampir seluruh ahli fiqh yang melarang keterlibatan perempuan sebagai pemimpin menggunakan hadis ini sebagai dalil. Belakangan mereka memberikan argumen penguat bahwa perempuan adalah makhluk yang kurang akalnya dan labil mentalnya. Sehingga tertutup peluang bagi perempuan untuk menempati jabatan pimpinan pada segala bidang yang mengurusi urusan orang banyak.

Statemen Rasulullah saw mengenai kehancuran yang akan dialami kaum yang menyerahkan urusannya kepada perempuan yang diungkapkan dalam hadis tersebut sejalan dengan realitas sejarah. Karena secara historis tercatat bahwa setelah Kisra menyerahkan kekuasaan kepada putranya, maka anaknya itu membunuh ayah dan saudara-saudara laki-lakinya. Setelah anak itu wafat, maka kekuasaan beralih ke tangan putri Kisra yang bernama Bavaran binti Syirawiyah bin Kisra, dimana di masa pemerintahannyalah kerajan Persia itu hancur.

Dari asbab al-wurudnya dapat diungkapkan bahwa hadis ini khusus berkaitan dengan kasus kerajaan Persia. Kalau pun ingin dipandang berlaku umum, maka hadis ini berkaitan dengan kekuasaan umum yang dipegang oleh seorang penguasa yang umum berlaku dalam negaranegara kerajaan (monarki). Dalam tradisi kerajaan yang menggunakan sistem monarki, raja memiliki otoritas penuh (kekuasaan absolut) dan menangani semua masalah kenegaraan, baik militer, pemerintahan (eksekutif), legislatif maupun pengadilan (yudikatif). Sehingga tidak ada sistem pembagian kekuasaan sebagaimana terjadi dalam sistem pemerintahan modern dewasa ini.

Dalam kondisi sosial politik di negara mana pun dewasa ini, hampir tidak ada sebuah jabatan apa pun yang memiliki otoritas penuh untuk membuat keputusan (legislatif), melaksanakannya (eksekutif), dan sekaligus mengontrolnya (yudikatif). Sebagaimana konsep kekhalifahan yang menempatkan khalifah sebagai pemimpin negara sekaligus pemimpin agama yang memiliki otoritas yang sangat besar. Konteks hadis Abi Bakrah di atas, menunjukkan bahwa putri kaisar Persia diserahi segala urusan dalam posisinya sebagai ratu, seperti yang ditunjukkan oleh kata "wallau" (memberikan kekuasaan). Inilah yang tidak disetujui Nabi saw. Hadis di atas berlaku secara khusus. Sehingga jika ada seorang perempuan memiliki kemampuan (keahlian/kecakapan) untuk menjabat pimpinan, maka di pos kepemimpinan mana pun dibolehkan oleh hukum Islam.

Dengan demikian dalalah hadis Abu Bakrah harus digunakan kaidah: al"ibrah bi khusus al-sabab la bi 'umum al-lafzi (yang dilihat adalah kekhusan sebab, bukan keumuman lafaz). Qurasih Shihab pun memandang hadis ini bersifat khusus. Hadis tersebut ditujukan kepada masyarakat Persia ketika itu, bukan terhadap semua masyarakat dan dalam semua urusan.

Dari segi dalil, hadis Abu Bakrah tidak cukup syarat untuk dijadikan pelarangan keterlibatan perempuan sebagai pemimpin. Karena menurut ushul fiqh, sebuah nash, baru dapat dikatakan menunjukkan larangan jika memuat setidaknya hal-hal berikut: 1. secara redaksional, nash dengan tegas mengatakan haram 2. nash dengan tegas melarangnya dalam bentuk nahi. 3. nash diiringi oleh ancaman 4. menggunakan redaksi lain yang menurut gramatika bahasa Arab menunjukkan tuntutan harus dilaksanakan.

Dengan demikian hadis di atas tidak melarang secara tegas perempuan menjabat tugas 
kepemimpinan. Tegasnya, bahwa kehancuran kerajaan Persia saat dipimpin oleh putri Kaisar bukan karena dia seorang perempuan namun lebih disebabkan oleh kecakapan atau keahliannya sebagai kepala negara. Sebab keahlian dalam kepemimpinan tidak semata-mata berkaitan dengan kodratnya, sebagai laki-laki atau perempuan. Tetapi lebih dipengaruhi oleh lingkungan dan kesempatan seseorang dalam mengakses informasi ilmu pengetahuan. Tingkat keahlian dalam memimpin justru lebih logis dilihat dari sudut sosiologis, bahkan secara tekstual ada hadis yang mengkaitkan kegagalan suatu urusan yang dipercayakan kepada orang yang tidak ahli (profesional).

Dalam hal ini Nabi saw bersabda:

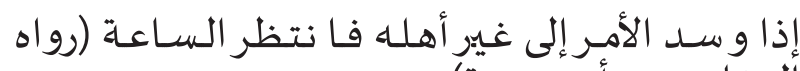
البخارى عن أبي هريرة إلى غيرة

Artinya:Apabila suatu urusan diserahkan kepada orang yang bukan ahlinya, maka waspadalah terhadap datangnya kehancuran.' (HR Bukhari dari Abu Hurairah)

Kata kehancuran (al-sa'ah) dalam hadis di atas berarti kebinasaan atau kehancuran, baik kehancuran kehidupan dunia pada hari kiamat maupun kehancuran di dunia ini akan dialami oleh kaum atau bangsa yang menyerahkan urusan umum (apalagi urusan kenegaraan) kepada orang yang tidak ahli.

Dengan demikian hadis Abu Bakrah berkaitan dengan ketidakcakapan putri Kaisar sebagai ratu (kepala negara) Persia dalam memimpin negaranya. Hal ini terjadi karena secara kultural di negara Persia, yang dididik untuk menggantikan raja adalah laki-laki sedangkan anak perempuan tidak diberi kesempatan mendapatkan pendidikan yang memadai. Jadi, bukan karena kodratnya sebagai perempuan yang menjadi pemicu negara Persia hancur di masa pemerintahannya. Kalau saja sang putri Kaisar mempunyai keahlian dalam memimpin negara Persia, maka kehancuran itu belum tentu terjadi.

Dalam konteks kepemimpinan putri kaisar Persia itulah pendapat Yusuf Qardawi sangat tepat. Menurut pendapat Yusuf Qardawi, bahwa perempuan dilarang menjadi kepala negara karena potensi perempuan biasanya tidak tahan untuk menghadapi situasi konfrontansi yang mengandung resiko berat. Karena model kepemimpinan kepala negara zaman klasik memang mengurus semua hal termasuk dalam masalah pertahanan negara sedangkan dalam sistem pemerintahan sekarang telah terjadi pembagian kekuasaan. Kepala negara tidak harus terjun langsung dalam masalahmasalah yang memang telah menjadi kewenangan bawahannya (Yusuf Qardawi, 1996: 37).

Berdasar pada asumsi keahlian dalam memimpin suatu urusan itu, maka perempuan boleh menjadi pemimpin. Bukan saja dalam tingkatan yang rendah, tetapi boleh menduduki jabatan publik di posisi puncak. Bukan saja sebagai hakim seperti pendapat Abu Hanifah, tetapi bisa menjadi kepala negara sekalipun. Tegasnya, bahwa perempuan boleh menjadi kepala negara, asalkan dia profesional atau cakap dalam memimpin negara.

Dengan demikian sebenranya perempuan dapat berperan dalam beberapa hal. Diantaranya dapat disebutkan: peran kodrati (peran reproduksi). Secara historis cultural, peran perempuan yang dikaitkan dengan kerumahtanggaan didasarkan pada kodrat perempuan yang mengarah pada aspek biologis. Kalau merujuk pada akar budaya dan agama, maka peran kodrati tidak hanya terbatas pada peran reproduktif (hamil, melahirkan dan menyusukan atau peran yang tidak bernilai uang), tetapi juga terjadi pada pembagian kerja domestik dan publik antar suami-isteri. Peran reproduktif dikatakan esensi dari peran kodrati karena ia tidak dapat digantikan oleh jenis jender lainnya, akan tetapi dalam proses melahirkan keturunan itu perlu dilibatkan jenis jender laki-laki. Keterlibatan lakilaki dan perempuan dalam melahirkan keturunan itu sangat diperlukan keabsahannya dalam Islam melalui perkawinan (Quraisy Syihab, 2005: 16).

Dari berbagai informasi dan hasil studi perempuan yang menyangkut peran kodratnya dapat ditemukan benang merahnya, bahwa peran yang dapat dikaitkan antara lain : 1) Proses sosialisasi dalam membina moral keluarga, membina kecerdasan dan keterampilannya dalam kemasan pendidikan sumber daya manusia seutuhnya, menegakkan budaya kerja, budaya bersih dan budaya tertib; 2) Pengelolaan anggaran belanja agar dapat terwujud keseimbangan, tidak boros tetapi juga tidak kikir; 3) Peran reproduksi berfungsi 
mengurangi jumlah kawin muda dan kawin cerai, serta membatasi jumlah kelahiran dengan program KB sesuai dengan petunjuk pemerintah dan agama; 4) Menegakkan keadilan dalam pembagian kerja agar tidak terjadi eksploitasi tenaga perempuan, karena sesuai kenyataan mereka bekerja lebih lama dibanding laki-laki disebabkan karena di samping mereka di luar, mereka juga masih bekerja 100 persen dalam urusan rumah tangga yang mungkin tanpa dibantu oleh suaminya (Rasdiyanah, 1999:12).

Peran ekonomi (peran produktif). Peran ini disebut esensi peran jender karena jelas peran ini dilakukan oleh laki-laki, namun kalau perempuan juga melakukannya atas kemauannya sendiri sebagai pilihan, berarti keduanya mempunyai peran yang serupa.

Peran ekonomi perempuan pada dasarnya tidak dapat diabaikan, namun kontribusi mereka kurang disadari baik oleh perempuan sendiri maupun oleh masyarakat luas. Pada dasarnya mereka merupakan tenaga kerja (di rumah tangganya) tetapi tidak dibayar dengan uang. Lain halnya jika pekerjaan rumah tangga dilakukan di tempat lain, maka mereka diberi status sebagai pekerja yang menerima imbalan tunai atau natura. Itulah sebabnya, maka dikatakan bahwa curahan waktu bekerja bagi perempuan lebih lama dan lebih panjang dibandingkan laki-laki, karena kalau perempuan bekerja di luar rumah, mencari nafkah, pekerjaan rumah tangga juga menjadi kewajibannya sehingga dikatakan bahwa peran mereka adalah peran ganda.

Peran sosial (peran kemasyarakatan). Kesadaran akan tingginya potensi perempuan selama ini dalam banyak hal tidak teraktualisasikan diakibatkan adanya stereotipe bahwa perempuan didominasi oleh emosi, dan laki-laki oleh rasio. Hal ini tertantang dengan munculnya gambaran baru bahwa laki-laki maupun perempuan sesungguhnya memiliki kedua unsur utama eros dan logos (pikiran dan perasaan cinta kasih) yang harus berjalan secara seimbang.

Kini orang sudah mulai melihat perlunya manusia bermulti fungsi: seorang perempuan berpeluang untuk jadi ilmuan yang sukses, isteri yang penyayang, sebagai ibu dan pendidik yang bijaksana, penulis yang berhasil serta pekerja sosial yang berbudi luhur. Tekhnolog dan profesionalisasi telah memungkinkan perempuan untuk mendapatkan keinginan dalam tugas rutin yang selama ini melilitnya. Dengan demikian terbuka peluang baginya untuk lebih berpartisipasi dalam tugas-tugas kemasyarakatannya dan berpartisipasi dalam bidang politik.

Untuk berperan dalam bidang politik maka tahap awal perlu diberikan kelonggaran posisi, sehingga kaum perempuan dapat berperan dalam pembuatan kebijakan di setiap strata pemerintahan. Di tingkat pusat, keputusan politik itu ada di tangan lembaga tertinggi dan lembaga tinggi negara dan oleh karena itu perlu ada kelonggaran keberadaan perwakilan perempuan di lembaga-lembaga terutama mengenai jumlahnya. Oleh karena itu, Lembaga Tertnggi dan Lembaga Tinggi Negara merupakan suatu produk dan proses demokrasi melalui pemilihan umum, maka di dalam Undangundang tentang Pemilihan Umumpun perlu adanya ketentuan yang memberikan kelonggaran terhadap peranan perempuan di dalam setiap Lembaga Pemerintah.

\section{PENUTUP}

Berdasarkan pembahasan yang telah diuraikan di atas, dapat disimpulkan bahwa peran perempuan dari berbagai aspek, baik itu dalam refroduksi, ekonomi, sosial, politik dan kepemimpinan Islam bahwa selama ini perempuan ditempatkan hanya sebagai anggota dalam hal kepengurusan, hal ini diungkapkan oleh berbagai informan bahwa perempuan yang aktif di organisasi kemasyarakatan serta tidak memiliki ciri-ciri pemberani seperti halnya dengan laki-laki. Alasan inilah sehingga program kerja yang diusulkan perempuan tidak begitu banyak untuk diterima dan implementasikan ke dunia politik yang ada.

Sedangkan Posisi perempuan dalam partai politik rata-rata bersifat stereotipe, hal ini dibuktikan dari hasil penelitian melalui wawancara dengan alasan bahwa dengan maupun tidak banyak dilibatkan dalam faktor-faktor yang mempengaruhi keterlibatan perempuan dalam partai politik adalah : pengaruh faktor pendidikan sangat besar dan sangat menentukan keaktifan kaum perempuan dalam keterlibatannya sebagai pengurus partai politik, karena semua tugas-tugas yang diembankan kepada perempuan dapat dilaksanakan berkat adanya pendidikan yang dimiliki oleh perempuan tersebut. 
Ini berarti bahwa ada relevansi antara tugas dengan pendidikan.

Kendala yang dialami perempuan dalam partai politik yaitu melalui beberapa persoalan antara lain pendidikan, pekerjaan, keadilan dan kesetaraan gender, peran domestik, budaya patriarki, agama dan hubungan kekeluargaan. Semua yang tercatat ini adalah masalah yang sering dihadapi perempuan dalam aspek kehidupan di masyarakat. Sehingga terkesan bahwa selama ini banyak perempuan yang tidak mau terlibat dengan persoalan partai, dan kemudian kendala lain yang sering terjadi di beberapa partai yaitu terjadinya diskriminasi terhadap perempuan bahkan ketidakadilan yang dialami oleh perempuan dalam partai politik.

Perempuan yang memiliki keahlian atau kompetensi memimpin negara, boleh menjadi kepala negara dalam konteks masyarakat modern karena sistem pemerintahan modern tidak sama dengan sistem monarki yang berlaku di masa klasik dimana kepala negara harus mengendalikan semua urusan kenegaraan.

\section{UCAPAN TERIMA KASIH}

Ucapan terima kasih kepada seluruh pihak yang turut membantu terlaksananya penelitian ini mulai dari awal sampai akhir. Ucapan terima kasih terkhusus pengelolah jurnal Al-Qalam yang telah memuat tulisan ini pada volume 29 No.1 2013.

\section{DAFTAR PUSTAKA}

Aisyah, T. 2002, Sosiologi Politik. Jakarta:PT. Raja GrafindoPersada.

al-Asqalani, Ahmad bin Ali bin Hajar. 1989, Fath alBari Syarh Sahih al-Bukhari, Juz VIII. Bayrut: Dar al-Kutub al-'Ilmiyyah ; Cet. I

Al-Bukhari, Muhammad bin Isma'il bin Ibrahim. 1992, Sahih al-Bukhari, Juz V. Bayrut: Dar alKutub al-'Ilmiyyah,.

---. Sahih al-Bukhari, t.th, Juz I. Semarang: Toha Putra

al-Khallaf, Abdul Wahab. 1987, 'Ilm al-Usul al-Fiqh. Kairo: Dar al-Falah,.

al-Qurtubi. 1990, Fi Zilal al-Quran, Juz II. Bayrut: Dar al-Tiras li al-'Arabi,

Al-Razi, Fakhru al-Din. 1990, al-Tafsir al-Kabir, Jilid XV. Bayrut: Dar al-Ihya al-Tiras al-Arabi,.
Al-Sijistani, Abu Daud Sulaiman bin al-Asy’as. 1990, Sunan Abi Daud, Juz III. Bayrut: Dar al-Fikr,.

Anees, Munawar Ahmad. 1993, Islam and Biological Futures: Ethics, Gender and Technolog, Diterjemahkan oleh Rahmani Astauti dengan judul Islam dan Masa Depan Biologis Umat Manusia: Etika, Gender dan Teknologi. Bandung: Mizan; Cet. III

Departemen Agama R.I. 2002, Al-Quran dan Terjemahnya. Jakarta: CV Indah Press.

Dian, H. 2002, Perspektif tentang Perubahan Sosial. Jakarta: PT. Rineka Cipta.

Fakih, Mansur. 2005, Analisis Gender \& Transformasi Sosial. Jakarta: Pustaka Pelajar

Izzat, Hibbah Rauf. 1997, al-Mar'ah wa al-Amal alSiyasi Ru'yah Islamiyyah. Diterjemahkan oleh Baharuddin al-Fanani dengan judul Wanita dan Politik Pandangan Islam. Bandung: PT Remaja Rosdakarya; Cet. I

Lukman, B. 1999, Implementasi Konsep dan Teori Sosiologi. Jakarta:. Penerbit Gramedia Pustaka Megawangi, Ratna. 1999, Membiarkan Berbeda Sudut Pandang Baru Tentang Relas Gender. Bandung: Mizan; Cet. I

Pasiak, Taufik. 2005, Revolusi IQ/EQ/SQ Antara Neurosains dan Al-Quran. Bandung: PT Mizan Pustaka ; Cet. V

Qardawi, Yusuf. 1996, Hady al-Islam Fatawi Mu'asirah. Diterjemahkan oleh As'ad Yasin dengan judul Fatwa-Fatwa Kontemporer, Jilid 2. Jakarta: PT Gema Insani Press; Cet. II

-_-. 2000, Malamih al-Mujtama' al-Muslim Allazi Nansyuduhu. Diterjemahkan oleh Setiawan Budi Utomo dengan judul Anatomi Masyarakat Muslim. Jakarta: Pustaka AlKautsar;Cet. II

Rasdiana, Andi, 1999. Seni dalam ritual Agama. Yogyakarta:Yayasan untuk Indonesia.

Rida, Muhammad Rasyid. 1992, Tafsir al-Manar, Juz II. Bayrut: Dar al-Kutub al-'Ilmiyya

Shihab, M. Quraish. 2005, Wawasan Al Quran Tafsir Maudhu'i atas Pelbagai Persoalan Umat Bandung: PT Mizan Pustaka; Cet. XVI

Subhan, Zaitunah. 1999, Tafsir Kebencian Studi Bias Gender Dalam Tafsir Quran. Yogyakarta: LkiS; Cet. I

Syarifuddin, Amir. 2002, Meretas Kebekuan Ijtihad Isu-isu Penting Hukum Islam Kontemporer Indonesia.; Jakarta: Ciputat Press; Cet. I 
Tjokrominoto.1996, Negara dan Nasionalime Indonesia. Jakartata: Gramedia.

Yies, George. 2002. Funcional Structural Theoty, New York : Published by McGrraw Hill 